\title{
The Relationship Between Generalized Joint Hypermobility and Adhesive Capsulitis of the Shoulder
}

\author{
Generalize Eklem Hipermobilitesi ve Omzun Adeziv Kapsüliti Arasındaki İlişki
}

\author{
Yeliz TERZİ, ${ }^{1}$ Kenan AKGÜN, ${ }^{1}$ İlknur AKTAŞ,, 1 Deniz PALAMAR, ${ }^{1}$ Günay CAN ${ }^{2}$ \\ ${ }^{1}$ Department of Physical Medicine and Rehabilitation, Medical Faculty of Sakarya University, Sakarya, Turkey \\ ${ }^{2}$ Department of Physical Medicine and Rehabilitation, İstanbul University Cerrahpaşa Medical Faculty, İstanbul, Turkey \\ ${ }^{3}$ Department of Physical Medicine and Rehabilitation, Fatih Sultan Mehmet Training and Research Hospital, Istanbul, Turkey \\ ${ }^{4}$ Department of Public Health, İstanbul University Cerrahpaşa Medical Faculty, İstanbul, Turkey
}

Objectives: This study aims to investigate the possible relationship between generalized joint hypermobility $(\mathrm{GJH})$ and adhesive capsulitis (AC) of the shoulder.

Patients and methods: A total of 240 patients were enrolled in this study, including 120 patients diagnosed with $A C$ in a study group and 120 patients diagnosed with primary subacromial impingement syndrome in the control group. We evaluated the pain severity, range of motion of the shoulder joint, functional status, disability, and hypermobility in both groups. The Beighton score was used to evaluate the GJH while the revised Brighton criteria were utilized for the patients with benign joint hypermobility syndrome (BJHS).

Results: In the adhesive capsulitis group, GJH was significantly rare $(p<0.05)$ with only one patient $(0.08 \%)$ whereas BJHS was not found. In the control group, nine patients (7.5\%) had $\mathrm{GJH}$, and five $(4.2 \%)$ had BJHS.

Conclusion: Our study results suggest that GJH may be a protective or preventive factor in the development of AC. In clinical practice, we believe that in GJH patients we can be more optimistic regarding the concern of the conversion of shoulder pain to $\mathrm{AC}$. If this has already taken place, then these patients may respond more positively to treatment in cases involving GJH.

Key words: Adhesive capsulitis; benign joint hypermobility syndrome; impingement syndrome.
Amaç: Bu çalışmada generalize eklem hipermobilitesi (GEH) ve omzun adeziv kapsüliti (AK) arasındaki muhtemel ilişki araştırıldı.

Hastalar ve yöntemler: Çalışma grubunda 120'si AK tanılı ve kontrol grubunda 120'si primer subakromiyal sıkışma sendromu tanılı olmak üzere, toplam 240 hasta çalışmaya dahil edildi. Her iki grupta da ağrı şiddeti, omuz eklem hareket açıklığı, fonksiyonel değerlendirme, engellilik ve hipermobilite değerlendirildi. Generalize eklem hipermobilitesi Beighton skoru, benign eklem hipermobilite sendromu (BEHS) ise revize Brighton kriterleri ile değerlendirildi.

Bulgular: Adeziv kapsülit grubunda, GEH sadece bir hastada $(\% 0.08)$ olmak üzere oldukça nadir $(p<0.05)$ saptanırken, BEHS'ye rastlanmadı. Kontrol grubunda ise dokuz hastada (\%7.5) GEH, beş hastada (\%4.2) BEHS gözlendi.

Sonuç: Çalışma bulgularımız, GEH'in AK gelişimi için koruyucu veya önleyici bir faktör olabileceğini göstermektedir. Klinik pratikte, GEH olan hastalarda gelişen omuz ağrılarında, tablonun AK'ye dönüşümü açısından daha iyimser olunabileceğine inanıyoruz. Generalize eklem hipermobilitesi bulunan hastalarda AK gelişimi söz konusu ise, bu hastalar tedaviye daha iyi yanıt verebilir.

Anahtar sözcükler: Adeziv kapsülit; benign eklem hipermobilite sendromu; sıkışma sendromu.

\footnotetext{
Received: October 23, 2012 Accepted: March 03, 2013

Correspondence: Deniz Palamar, M.D. İstanbul Üniversitesi Cerrahpaşa Tıp Fakültesi Fiziksel Tıp ve Rehabilitasyon Anabilim Dalı, 34098 Cerrahpaşa, Fatih, İstanbul, Turkey. Tel: +90 533 - 3321879 e-mail: denizpalamar@gmail.com

Presented at the $5^{\text {th }}$ World Congress of the ISPRM, June 13-17, 2009, İstanbul, Turkey.

(O2013 Turkish League Against Rheumatism. All rights reserved.
} 
The shoulder is a joint where soft tissue pathologies are commonly observed due to its complex anatomic structure. One of these pathologies, adhesive capsulitis $(\mathrm{AC})$, is a painful syndrome characterized by the progressive limitation of active and passive range of motion (ROM). ${ }^{[1]}$

Joint hypermobility is a condition related to ligamentous laxity that causes increased ROM in the joints. It is most often generalized but may also involve a single joint. When generalized joint hypermobility $(\mathrm{GJH})$ is symptomatic, it is known as benign joint hypermobility syndrome (BJHS). ${ }^{[2-4]}$

The common characteristic of GJH and AC is the presence of collagen-related disorders in their pathophysiology. The intensity of collagen fibrils increase, and their arrangement becomes irregular in AC. In addition, thickening and adherences occur in the shoulder joint capsule. As a result of the capsular contracture, both active and passive shoulder ROM is limited. ${ }^{[1,5,6]}$ However, the collagen fibrils have a thinner and more irregular structure in $\mathrm{GJH}$, and these abnormalities lead to laxity of the joints, increased fragility of the connective tissue, and decreased proprioception. In turn, this results in a predisposition toward joint degeneration and soft tissue injuries. ${ }^{[2,7]}$ Among these two pathologies that stem from collagen disorders, increased and limited joint ROM is observed in $\mathrm{GJH}$ and $\mathrm{AC}$, respectively. Due to these two different clinical conditions, we hypothesized that GJH might play a protective or preventive role against the development of AC. Herein, the relationship between $\mathrm{AC}$ and $\mathrm{GJH}$, which appear to be two different pathologies, was investigated.

\section{PATIENTS AND METHODS}

The patients who presented to the shoulder outpatient clinic of Physical Medicine and Rehabilitation Department, Cerrahpasa Medical Faculty between July 2005 and September 2007 with complaints of shoulder pain and/or limitated ROM were evaluated. A total of 240 patients were enrolled in this study, with a study group of 120 patients diagnosed with AC and a control group of 120 patients diagnosed with primary subacromial impingement syndrome (SIS). The local ethics committee approved the procedures followed in this study, and after the patients were informed about the study procedure, they gave their and written informed consent to be included in our cohort.

Diagnosis of the shoulder pathology was based on the patient's history, a clinical examination, conventional radiography, a subacromial injection test (SIT), and magnetic resonance imaging (MRI) as well as electroneuromyography when needed. Routine biochemistry and immunological laboratory tests were also performed if necessary to rule out the diseases mentioned in the exclusion criteria. Besides a routine physical examination of the cervical spine and shoulder joint, we measured the active and passive ROM and performed special tests on the shoulder to determine the diagnosis.

We performed the SIT as a reference test. A patient was diagnosed with AC if they had active and passive ROM limitations together with the absence of improvement on the SIT. These cases constituted the study group. The patients with positive impingement tests (Neer, Hawkins-Kennedy, and painful arc tests) along with a positive SIT were diagnosed with primary SIS. ${ }^{[8,9]}$ These cases constituted the control group with disease.

Exclusion criteria were the following: (i) patients older than 70 years old and younger than 18, (ii) a history of shoulder surgery, (iii) the presence of cervical pain, (iv) the presence of inflammatory, infectious, or systemic diseases, ( $v$ ) malignancy, ( $v i)$ the presence of psychiatric disorders and cognitive dysfunction, (vii) the presence of neurological and vascular diseases, (viii) the presence of instability, labral lesions, calcific tendinitis, glenohumeral joint osteoarthritis (OA), or entrapment neuropathy in the shoulder region, (ix) shoulder dislocation and/or fracture, and ( $x$ ) patients who frequently participated in sports activities that involved a throwing motion.

\section{Group evaluation}

Pain measurement, shoulder joint ROM, functional assessment, disability, and hypermobility evaluations were done in both groups by the first investigator.

Shoulder pain at rest and during activity along with pain which disturbed the normal sleep patterns were evaluated using a numeric pain scale (NPS). ${ }^{[10]}$ The shoulder's active and passive ROM (flexion, extension, abduction, adduction, and internal and external rotation) were measured via goniometry, ${ }^{[1]}$ and the functional assessment was calculated according to the Constant-Murley scale. ${ }^{[12]}$ In addition, the Turkish version of the Shoulder Disability Questionnaire (SDQ) was used to evaluate disability. ${ }^{[13,14]}$ All subjects were assessed 


\begin{tabular}{|c|c|c|c|c|c|c|}
\hline & \multicolumn{2}{|c|}{ Group 1 (AC) } & \multicolumn{2}{|c|}{ Group 2 (SIS) } & \multirow[b]{2}{*}{ Chi-square } & \multirow[b]{2}{*}{$p$} \\
\hline & $\mathrm{n}$ & $\%$ & $\mathrm{n}$ & $\%$ & & \\
\hline Male & 48 & 40.0 & 26 & 21.7 & & \\
\hline Female & 72 & 60.0 & 94 & 78.3 & 9.45 & $0.002^{* *}$ \\
\hline
\end{tabular}

for the existence of GJH using the Beighton score ${ }^{[15]}$ and for BJHS using the revised Brighton criteria. ${ }^{[16]}$

\section{Statistical analysis}

The data was evaluated using the SPSS for Windows version 10.0 software program (SPSS Inc., Chicago, IL, USA). Student's t-test was used for comparing parametric data, such as age, body mass index (BMI), and ROM, whereas the Mann-Whitney $U$ test was utilized for comparing the duration of symptoms, pain scores, and Beighton scores. Furthermore, a chi-square and Fisher's exact tests were used for comparing the categorical variables. A $p$ value of $<0.001$ was considered to be highly significant, a $p$ value of $<0.01$ was moderately significant, and a $p$ value of $<0.05$ was significant.

To calculate the sample size, the prevalence of hypermobility was estimated to be approximately $10 \%$ in the SIS group and $1 \%$ in the AC group. In order to reach $80 \%$ power and a $95 \%$ confidence interval (CI), 120 patients were enrolled in each of these groups.

\section{RESULTS}

In both the SIS and AC groups, the proportion of females was higher than males, with the number of females being significantly higher in the SIS group compared with the AC group $(\mathrm{p}<0.01)$ (Table 1$)$.

The patient's other characteristics are shown in Table 2. No significant differences were found between the groups in terms of age, shoulder pain, and symptom duration. However, a significant difference was observed in the two groups $(p<0.001)$ when comparing the shoulder ROM. The ROM was markedly preserved in the SIS group but considerably limited in the AC group in all directions. In line with this, the total score for the Constant-Murley functional evaluation scale was significantly higher in the SIS group compared with the AC group $(\mathrm{p}<0.001)$, but no significant differences were noted between the total SDQ scores ( $\mathrm{p}>0.05)$.
In the SIS group, the number of cases with GJH and BJHS were markedly higher $(p<0.05)$, but only one patient $(0.08 \%)$ was diagnosed with GJH in the AC group, and none had BJHS. In contrast, in the control group, nine patients $(7.5 \%)$ had GJH while five (4.2\%) had BJHS (Table 3). Moreover, the total Beighton scores were significantly higher in the SIS group than the AC group $(\mathrm{p}<0.001)$ (Table 4$)$.

\section{DISCUSSION}

In the present study, we investigated the clinical relationship between GJH and AC which involve different collagen disorders in their etiopathogenesis, and GJH was found at a significantly lower rate in the AC group than the control group with SIS.

The prevalence of $\mathrm{AC}$ is $2-5 \%$ in the overall population $^{[6,17]}$ while it is between $10-20 \%$ for $\mathrm{GJH} \cdot{ }^{[2,3,18]}$ Studies that have focused on the prevalence GJH have mostly been conducted using younger populations, especially school age children. There have been very few of these types of studies performed on adults. ${ }^{[2,4]}$ In these studies, it is common to use the definitions for GJH and BJHS interchangeably instead of providing separate, distinct definitions. Although mostly known as a syndrome, GJH is primarily evaluated using only the Beighton scoring system. Additionally, the actual prevalence of BJHS, despite being less frequent than GJH, is still not known. ${ }^{[3,7]}$

Adhesive capsulitis is more common in females, occurring at a rate of $55-70 \% .^{[1,5]}$ Similarly, the studies performed on different groups according to ethnic origin have revealed a $\mathrm{GJH}$ rate varying between 5 and $57 \%$ in females and 2 and $35 \%$ in males. ${ }^{[19,20]}$ In our study, females constituted $60 \%$ of the $\mathrm{AC}$ group, whereas only the single GJH patient in the study group and eight of the nine GJH patients in the control group were females. Adhesive capsulitis is most commonly idiopathic in nature. ${ }^{[6,21]}$ While there are investigators who accept concomitant diseases such as diabetes and hyperthyroidism as also being idiopathic, others consider these to be secondary 
Table 2. Clinical characteristics of the patients

\begin{tabular}{|c|c|c|c|c|c|c|c|}
\hline & \multicolumn{3}{|c|}{ Group 1 (AC) } & \multicolumn{3}{|c|}{ Group 2 (SIS) } & \multirow[b]{2}{*}{$p$} \\
\hline & Mean \pm SD & Median & Min.-max. & Mean \pm SD & Median & Min.-max. & \\
\hline Age (years) & $53.97 \pm 8.21$ & & & $54.08 \pm 10.68$ & & & 0.930 \\
\hline Body mass index $\left(\mathrm{kg} / \mathrm{m}^{2}\right)$ & $25.43 \pm 4.40$ & & & $27.67 \pm 4.95$ & & & $<0.001^{\star}$ \\
\hline Duration of symptoms (days) & & 127.5 & $30-720$ & & 120 & $10-720$ & 0.136 \\
\hline Resting pain (NPS) & & 3 & $0-10$ & & 3.5 & $0-9$ & 0.395 \\
\hline Activity pain (NPS) & & 7 & $0-10$ & & 7 & $3-10$ & 0.682 \\
\hline Pain disturbing sleep (NPS) & & 6 & $0-10$ & & 5.5 & $0-10$ & 0.879 \\
\hline Active abduction $\left({ }^{\circ}\right)$ & $84.79 \pm 22.26$ & & & $174.08 \pm 15.10$ & & & $<0.001^{*}$ \\
\hline Active adduction (o) & $31.83 \pm 8.30$ & & & $41.58 \pm 5.14$ & & & $<0.001^{\star}$ \\
\hline Active extantion $\left({ }^{\circ}\right)$ & $32.00 \pm 9.45$ & & & $41.83 \pm 4.53$ & & & $<0.001^{*}$ \\
\hline Active flexion $\left(^{\circ}\right)$ & $91.17 \pm 20.44$ & & & $173.46 \pm 14.37$ & & & $<0.001^{*}$ \\
\hline $\begin{array}{l}\text { Active internal rotation } \\
\quad\left(\text { neutral arm position) }\left({ }^{\circ}\right)\right.\end{array}$ & $31.83 \pm 9.17$ & & & $41.50 \pm 5.00$ & & & $<0.001^{*}$ \\
\hline $\begin{array}{l}\text { Active external rotation } \\
\quad \text { (neutral arm position) }\left({ }^{\circ}\right)\end{array}$ & $25.79 \pm 11.06$ & & & $42.54 \pm 4.49$ & & & $<0.001^{*}$ \\
\hline $\begin{array}{l}\text { Active internal rotation } \\
\quad\left(\text { arm in abduction position) }\left(^{\circ}\right)\right.\end{array}$ & $25.33 \pm 16.90$ & & & $63.13 \pm 16.90$ & & & $<0.001^{\star}$ \\
\hline $\begin{array}{l}\text { Active external rotation } \\
\quad\left(\text { arm in abduction position) }\left({ }^{\circ}\right)\right.\end{array}$ & $33.38 \pm 21.27$ & & & $71.29 \pm 15.36$ & & & $<0.001^{\star}$ \\
\hline Passive abduction $\left({ }^{\circ}\right)$ & $96.92 \pm 24.96$ & & & $180.00 \pm 0.00$ & & & $<0.001^{\star}$ \\
\hline Passive adduction $\left(^{\circ}\right)$ & $36.00 \pm 8.03$ & & & $47.96 \pm 2.47$ & & & $<0.001^{*}$ \\
\hline Passive extension $\left({ }^{\circ}\right)$ & $36.21 \pm 8.15$ & & & $47.92 \pm 2.48$ & & & $<0.001^{\star}$ \\
\hline Passive flexion $\left({ }^{\circ}\right)$ & $100.04 \pm 20.02$ & & & $180.00 \pm 0.00$ & & & $<0.001^{\star}$ \\
\hline $\begin{array}{l}\text { Passive internal rotation } \\
\quad \text { (neutral arm position) }\left({ }^{\circ}\right)\end{array}$ & $34.63 \pm 8.99$ & & & $48.08 \pm 2.44$ & & & $<0.001^{*}$ \\
\hline $\begin{array}{l}\text { Passive external rotation } \\
\quad \text { (neutral arm position) }\left(^{\circ}\right)\end{array}$ & $30.38 \pm 11.63$ & & & $48.58 \pm 2.26$ & & & $<0.001^{\star}$ \\
\hline $\begin{array}{l}\text { Passive internal rotation } \\
\qquad\left(\text { arm in abduction position) }\left(^{\circ}\right)\right.\end{array}$ & $34.33 \pm 22.03$ & & & $90.00 \pm 0.00$ & & & $<0.001^{\star}$ \\
\hline $\begin{array}{l}\text { Passive external rotation } \\
\quad\left(\text { arm in abduction position) }\left(^{\circ}\right)\right.\end{array}$ & $44.21 \pm 25.00$ & & & $90.00 \pm 0.00$ & & & $<0.001^{\star}$ \\
\hline Constant-Murley total score & $33.32 \pm 10.81$ & & & $54.21 \pm 8.88$ & & & $<0.001^{\star}$ \\
\hline SDQ score & $80.64 \pm 18.41$ & & & $80.13 \pm 21.89$ & & & 0.636 \\
\hline
\end{tabular}

to AC. ${ }^{[6,21,22]}$ In this study, the rate of concomitant diabetes was $31.7 \%$ in the AC group and $11.7 \%$ in the SIS group.

In the literature, many concomitant diseases have been reported with GJH or BJHS. For example, in a study by Biro et al., ${ }^{[23]} 5.7 \%$ of the cases referred to an arthritis clinic and a pediatric rheumatology polyclinic determined that hypermobility syndrome was the underlying pathology. In addition, Bridges et al. ${ }^{[24]}$ found joint hypermobility in $15 \%$ of adult patients referred to a rheumatologist. Moreover, Ofluoğlu et al. ${ }^{[25]}$ and Şendur et al. ${ }^{[26]}$ found a BJHS rate of $64.2 \%$ and $46.6 \%$ respectively in women with fibromyalgia, and Nijs et al. ${ }^{[27]}$ reported a GJH rate of $20.6 \%$ in 68 cases with chronic fatigue syndrome and a rate of $4.3 \%$ in the healthy control group. Furthermore, Aktaş et al. ${ }^{[28]}$ demonstrated that BJHS is a predisposing factor for carpal tunnel syndrome, and Bird et al. ${ }^{[29]}$ found that there was an increased risk of OA due to joint overloading associated with an abnormal increase in joint ROM and decreased proprioception in cases with BJHS. Finally, el-Shahaly et al. ${ }^{[30]}$ found an OA 


\begin{tabular}{|c|c|c|c|c|c|c|}
\hline & \multicolumn{2}{|c|}{ Group 1 (AC) } & \multicolumn{2}{|c|}{ Group 2 (SIS) } & \multirow[b]{2}{*}{ Chi-square } & \multirow[b]{2}{*}{$p$} \\
\hline & $\mathrm{n}$ & $\%$ & $\mathrm{n}$ & $\%$ & & \\
\hline \multicolumn{7}{|c|}{ Generalized joint hypermobility } \\
\hline No & 119 & 99.2 & 111 & 92.5 & & \\
\hline Yes & 1 & 0.8 & 9 & 7.5 & 6.67 & $0.010^{\star}$ \\
\hline \multicolumn{7}{|c|}{ Benign joint hypermobility syndrome } \\
\hline No & 120 & 100 & 115 & 95.8 & & \\
\hline Yes & & & 5 & 4.2 & 5.10 & $0.024^{\star}$ \\
\hline
\end{tabular}

rate of $60 \%$ in cases with BJHS who presented to a rheumatology clinic, but the rate dropped to only $30 \%$ for those without BJHS.

The studies that investigated the relationship between shoulder pathologies and hypermobility demonstrated a correlation between GJH and glenohumeral joint laxity ${ }^{[31]}$ and instability. ${ }^{[32]}$ In the study by Cooper and Brems, ${ }^{[33]}$ they diagnosed GJH in 29 of the 38 cases with multi-directional shoulder instability. However, some investigators observed no correlation between generalized joint laxity and glenohumeral joint laxity ${ }^{[34]}$ and instability. ${ }^{[35,36]}$ Although there have been no trials that have evaluated SIS and GJH together, the classification by Jobe at al., ${ }^{[37]}$ who developed new insights into impingement syndrome in athletes, particularly gives credence to $\mathrm{GJH}$-associated instability and the resulting secondary impingement, that occurs in athletes under the age of 35 who perform throwing activites or overhead movements. The patients with SIS in our control group had no accompanying instability included in the primary impingement based on Neer's classification. ${ }^{[8]}$ We also found no studies in the literature that have focused on hypermobility in AC cases. The chronic inflammatory process, especially when it is triggered by various cytokines, has been held responsible for the AC pathophysiology. ${ }^{[38-40]}$ In addition, the plateletderived growth factor and the transforming growth factor beta $(\beta)$ values were higher in AC pathologies. ${ }^{[40]}$ Furthermore, an increase in fibroblast proliferation and fibrosis was also detected by Hannafin et al. ${ }^{[39]}$ In addition, Bunker ${ }^{[41]}$ observed intense type III collagen along with increased myofibroblasts and fibroblasts in the rotator interval and coracohumeral ligament in patients with AC. Nevisaer ${ }^{[42]}$ arthroscopically defined four stages in idiopathic AC: synovitis, capsular thickening, adhesion, and contracture. ${ }^{[42]}$ As seen in various studies, the AC physiopathology involves an impaired collagen structure, collagen intensity, and increased fibroblastic activity and contracture, ${ }^{[38-42]}$ whereas GJH and BJHS involve an impaired type I collagen structure and an increase in the type III collagen rate relative to type I. Furthermore, defective collagen production along with cross-link and stabilization abnormalities result in a decreased stretching resistance. ${ }^{[2,3,43-45]}$

Marfan syndrome (MS), Ehlers-Danlos syndrome (EDS) and osteogenesis imperfecta (OI), a group of diseases accompanied by systemic organ disorders involving joint hypermobility, are excluded from BJHS. Some patients with these diseases, have reported congenital joint and soft tissue contractures accompanying joint hypermobility, which is contrary to the hypothesis of this study. ${ }^{[46,47]}$ In BJHS, a nonpathogenic polymorphism occurs due to minor variations in the extracellular matrix genes, for example collagen, elastin, and fibrillin. With MS, EDS and OI, major variations and variations in the protein-binding points occur in the extracellular matrix genes, leading to severe organ disorders. ${ }^{[47,48]}$

Table 4. Evaluation of the total Beighton scores in both groups

\begin{tabular}{|c|c|c|c|c|c|}
\hline & \multicolumn{2}{|c|}{ Group 1 (AC) } & \multicolumn{2}{|c|}{ Group 2 (SIS) } & \multirow[b]{2}{*}{$p$} \\
\hline & Median & Min.-max. & Median & Min.-max. & \\
\hline Total Beighton scores & 0 & $0-4$ & 0 & $0-9$ & $0.001^{*}$ \\
\hline
\end{tabular}


In the literature, favorable effects associated with GJH and BJHS have also been reported. Hypermobility has been demonstrated to provide a protective effect against bone injury by enhancing the stretching property of the ligament and joint capsule in cases of spinal cord injuries in childhood. ${ }^{[49]}$ Hypermobility of the wrist and fingers has also been reported to enhance the performance skills in individuals who play musical instruments. ${ }^{[50]}$ Additionally, Kraus et al. ${ }^{[51]}$ found that hypermobility did not increase OA development in hand joints and that it had a protective effect in proximal interphalangeal joint OA. Furthermore, Krivickas and Feinberg ${ }^{[52]}$ demonstrated that lower extremity injuries were more common in athletes without hypermobility.

In our study, only one patient $(0.8 \%)$ with $\mathrm{AC}$ was found to have GJH. This patient could only reach 4 points on the Beighton scoring system. In the SIS group, nine patients $(7.5 \%)$ had $\mathrm{GJH}$, and five $(4.2 \%)$ of these also had BJHS.

The lack of a third group without any shoulder pathology in this study might be considered a limitation. In our outpatient clinic, the data for a similar age group without any shoulder pathology indicated that $7.1 \%$ of the patients had GJH and 3.9\% had BJHS. In addition, in a study by Nijs et al. ${ }^{[27]}$ that involved similar age groups, GJH was detected at a rate of $4.3 \%$ in the healthy control group ${ }^{[27]}$ and Kraus et al. ${ }^{[51]}$ detected a rate of $3.7 \%$ in another trial. With this data already in mind, we proceeded with our study and determined that the numbers of patients with GJH and BJHS were markedly higher in the SIS group $(\mathrm{p}<0.05)$ compared with $\mathrm{AC}$ group and the control subjects.

Despite the exclusion of the presence of instability in our cases, joint laxity and shoulder joint instability are concomitant conditions that are not easy to distinguish. Because of the presence of minor instability, a clinical examination may not detect shoulder joint instability. ${ }^{[53,54]}$ Furthermore, in individuals with $\mathrm{GJH}$, the increased movement of the shoulder joint may cause SIS. According to our study, the GJH and BJHS rates were higher in the SIS group than in the group made up of healthy subjects.

\section{Conclusion}

The available data shows that GJH may be a protective or preventive factor against the development of AC with capsular contracture.
Considering the implications of this favorable effect on the clinical practice, we believe that in GJH patients we can be more optimistic regarding the concern of the conversion of shoulder pain to AC. If this has already taken place, then these patients may respond more positively to treatment in cases involving GJH.

\section{Declaration of conflicting interests}

The authors declared no conflicts of interest with respect to the authorship and/or publication of this article.

\section{Funding}

The authors received no financial support for the research and/or authorship of this article.

\section{REFERENCES}

1. Neviaser RJ, Neviaser TJ. The frozen shoulder. Diagnosis and management. Clin Orthop Relat Res 1987;223:59-64.

2. Hakim A, Grahame R. Joint hypermobility. Best Pract Res Clin Rheumatol 2003;17:989-1004.

3. Simmonds JV, Keer RJ. Hypermobility and the hypermobility syndrome. Man Ther 2007;12:298-309.

4. Beighton P, Grahame R, Bird H. Hypermobility of joints. New York: Springer- Verlag; 1983.

5. Scanderbeg AC. Joint contracture, joint stiffness. Histo Anatomy Physiol Bone 1995;8:473-500.

6. Zuckerman JD, Cuomo F, Rokito S. Definition and classification of frozen shoulder. J Shoulder Elbow Surg 1994;3:S5.

7. Juul-Kristensen B, Røgind H, Jensen DV, Remvig L. Inter-examiner reproducibility of tests and criteria for generalized joint hypermobility and benign joint hypermobility syndrome. Rheumatology (Oxford) 2007;46:1835-41.

8. Neer CS 2nd. Impingement lesions. Clin Orthop Relat Res 1983;173:70-7.

9. Caliş M, Akgün K, Birtane $M$, Karacan I, Caliş H, Tüzün F. Diagnostic values of clinical diagnostic tests in subacromial impingement syndrome. Ann Rheum Dis 2000;59:44-7.

10. Price DD, McGrath PA, Rafii A, Buckingham B. The validation of visual analogue scales as ratio scale measures for chronic and experimental pain. Pain 1983;17:45-56.

11. Norkin CC, White DJ. Measurement of joint motion: a guide to goniometry. Philadelphia: F.A. Davis Company; 1995.

12. Constant CR, Murley AH. A clinical method of functional assessment of the shoulder. Clin Orthop Relat Res 1987;160-4.

13. Ozsahin M, Akgun K, Aktas I, Kurtais Y. Adaptation of the Shoulder Disability Questionnaire to the Turkish population, its reliability and validity. Int J Rehabil Res 2008;31:241-5. 
14. van der Heijden GJ, Leffers P, Bouter LM. Shoulder disability questionnaire design and responsiveness of a functional status measure. J Clin Epidemiol 2000;53:29-38.

15. Beighton P, Solomon L, Soskolne CL. Articular mobility in an African population. Ann Rheum Dis 1973;32:413-8.

16. Grahame R, Bird HA, Child A. The revised (Brighton 1998) criteria for the diagnosis of benign joint hypermobility syndrome (BJHS). J Rheumatol 2000;27:1777-9.

17. Sheridan MA, Hannafin JA. Upper extremity: emphasis on frozen shoulder. Orthop Clin North Am 2006;37:531-9.

18. Simpson MR. Benign joint hypermobility syndrome: evaluation, diagnosis, and management. J Am Osteopath Assoc 2006;106:531-6.

19. Al-Rawi ZS, Al-Aszawi AJ, Al-Chalabi T. Joint mobility among university students in Iraq. $\mathrm{Br} \mathrm{J}$ Rheumatol 1985;24:326-31.

20. Larsson LG, Baum J, Mudholkar GS, Srivastava DK. Hypermobility: prevalence and features in a Swedish population. Br J Rheumatol 1993;32:116-9.

21. Brue S, Valentin A, Forssblad M, Werner S, Mikkelsen C, Cerulli G. Idiopathic adhesive capsulitis of the shoulder: a review. Knee Surg Sports Traumatol Arthrosc 2007;15:1048-54.

22. Warner JJ. Frozen Shoulder: Diagnosis and Management. J Am Acad Orthop Surg 1997;5:130-140.

23. Biro F, Gewanter HL, Baum J. The hypermobility syndrome. Pediatrics 1983;72:701-6.

24. Bridges AJ, Smith E, Reid J. Joint hypermobility in adults referred to rheumatology clinics. Ann Rheum Dis 1992;51:793-6.

25. Ofluoglu D, Gunduz OH, Kul-Panza E, Guven Z. Hypermobility in women with fibromyalgia syndrome. Clin Rheumatol 2006;25:291-3.

26. Sendur OF, Gurer G, Bozbas GT. The frequency of hypermobility and its relationship with clinical findings of fibromyalgia patients. Clin Rheumatol 2007;26:485-7.

27. Nijs J, Aerts A, De Meirleir K. Generalized joint hypermobility is more common in chronic fatigue syndrome than in healthy control subjects. J Manipulative Physiol Ther 2006;29:32-9.

28. Aktas I, Ofluoglu D, Albay T. The relationship between benign joint hypermobility syndrome and carpal tunnel syndrome. Clin Rheumatol 2008;27:1283-7.

29. Bird HA, Tribe CR, Bacon PA. Joint hypermobility leading to osteoarthrosis and chondrocalcinosis. Ann Rheum Dis 1978;37:203-11.

30. el-Shahaly HA, el-Sherif AK. Is the benign joint hypermobility syndrome benign? Clin Rheumatol 1991;10:302-7.

31. McFarland EG, Campbell G, McDowell J. Posterior shoulder laxity in asymptomatic athletes. Am J Sports Med 1996;24:468-71.

32. Pollock RG, Bigliani LU. Recurrent posterior shoulder instability. Diagnosis and treatment. Clin Orthop Relat Res 1993;291:85-96.
33. Cooper RA, Brems JJ. The inferior capsular-shift procedure for multidirectional instability of the shoulder. J Bone Joint Surg [Am] 1992;74:1516-21.

34. Sauers EL, Borsa PA, Herling DE, Stanley RD. Instrumented measurement of glenohumeral joint laxity and its relationship to passive range of motion and generalized joint laxity. Am J Sports Med 2001;29:143-50.

35. Emery RJ, Mullaji AB. Glenohumeral joint instability in normal adolescents. Incidence and significance. J Bone Joint Surg [Br] 1991;73:406-8.

36. Lintner SA, Levy A, Kenter K, Speer KP. Glenohumeral translation in the asymptomatic athlete's shoulder and its relationship to other clinically measurable anthropometric variables. Am J Sports Med 1996;24:716-20.

37. Jobe FW, Kvitne RS, Giangarra CE. Shoulder pain in the overhand or throwing athlete. The relationship of anterior instability and rotator cuff impingement. Orthop Rev 1989;18:963-75.

38. Handa A, Gotoh M, Hamada K, Yanagisawa K, Yamazaki H, Nakamura M, et al. Vascular endothelial growth factor 121 and 165 in the subacromial bursa are involved in shoulder joint contracture in type II diabetics with rotator cuff disease. J Orthop Res 2003;21:1138-44.

39. Hannafin JA, DiCarlo EF, Wickiewicz TL. Adhesive capsulitis: capsular fibroplasia of the glenohumeral joint. J Shoulder Elbow Surg 1994;3(Suppl 1):5.

40. Rodeo SA, Hannafin JA, Tom J, Warren RF, Wickiewicz TL. Immunolocalization of cytokines and their receptors in adhesive capsulitis of the shoulder. J Orthop Res 1997;15:427-36.

41. Bunker TD. Frozen shoulder: unravelling the enigma. Ann R Coll Surg Engl 1997;79:210-3.

42. Neviaser JS. Adhesive capsulitis of the shoulder; a study of the pathologic findings in periarthritis of the shoulder. J Bone Joint Surg 1945;27:211-22.

43. Han XY, Wang W, Komulainen J, Koskinen SO, Kovanen V, Vihko V, et al. Increased mRNAs for procollagens and key regulating enzymes in rat skeletal muscle following downhill running. Pflugers Arch 1999;437:857-64.

44. Grahame R. Joint hypermobility and genetic collagen disorders: are they related? Arch Dis Child 1999;80:188-91.

45. Malfait F, Hakim AJ, De Paepe A, Grahame R. The genetic basis of the joint hypermobility syndromes. Rheumatology (Oxford) 2006;45:502-7.

46. Oz B, Olmez N, Memis A. Osteogenesis imperfecta: a case with hand deformities. Clin Rheumatol 2005;24:565-8.

47. Woerdeman LAE, Rit B, Maas MM. Wrist problems in patients with Ehlers-Danlos syndrome. Eur J Plast Surg 2000;23:208-10.

48. Milewicz DM. Molecular genetics of Marfan syndrome and Ehlers-Danlos type IV. Curr Opin Cardiol 1998;13:198-204. 
49. Beck A, Gebhard F, Kinzl L, Rüter A, Hartwig E. Spinal cord injury without radiographic abnormalities in children and adolescents: case report of a severe cervical spine lesion and review of literature. Knee Surg Sports Traumatol Arthrosc 2000;8:186-9.

50. Larsson LG, Baum J, Mudholkar GS, Kollia GD. Benefits and disadvantages of joint hypermobility among musicians. N Engl J Med 1993;329:1079-82.

51. Kraus VB, Li YJ, Martin ER, Jordan JM, Renner JB, Doherty $\mathrm{M}$, et al. Articular hypermobility is a protective factor for hand osteoarthritis. Arthritis Rheum 2004;50:2178-83.
52. Krivickas LS, Feinberg JH. Lower extremity injuries in college athletes: relation between ligamentous laxity and lower extremity muscle tightness. Arch Phys Med Rehabil 1996;77:1139-43.

53. Johnson SM, Robinson CM. Shoulder instability in patients with joint hyperlaxity. J Bone Joint Surg [Am] 2010;92:1545-57.

54. Nordenson U, Garofalo R, Conti M, Linger E, Classon J, Karlsson J, et al. Minor or occult shoulder instability: an intra-articular pathology presenting with extra-articular subacromial impingement symptoms. Knee Surg Sports Traumatol Arthrosc 2011;19:1570-5. 